\title{
THE TERMINAL APHONIA OF ALEXANDER THE GREAT, A SILENT HERALD OF AN ORDINARY DEATH
}

\author{
TERMINALNA AFONIJA ALEKSANDRA \\ VELIKOG, TIHOGA GLASNIKA OBIČNE SMRTI
}

\author{
Ernesto Damiani", Martina Elice ${ }^{* *}$, Rita Peca Conti***
}

\begin{abstract}
SumMARY
Even though the absence of the body prevents sure conclusions, the death of Alexander the Great remains a hot topic of retrospective diagnosis. Due to the serious mishandling of ancient sources, the scientific literature had Alexander dying of every possible natural cause. In previous works, the hypothesis that typhoid fever killed Alexander was proposed, based on the presence of the remittent fever typical of this disease in the narrations of Plutarch and Arrian. Here we provide additional evidence for the presence of stupor, the second distinctive symptom of typhoid fever. In fact, based on the authority of Caelius Aurelianus and Galen, we demonstrate that the word ö $\varphi \omega v o \varsigma$, used to describe the last moments of Alexander, is a technical word of the lexicon of the pathology of Hippocrates. Used by him, the word defines a group of diseases sharing a serious depression of consciousness and motility. The association of stupor with the remittent fever strengthens the typhoid fever hypothesis.
\end{abstract}

Keywords: death of Alexander the Great, remittent fever, stupor, aphonia, Caelius Aurelianus, Galen, Hippocrates, typhoid state

* Department of Biomedical Sciences, School of Medicine, University of Padova, Padova, Italy.

** Department of Historical and Geographic Sciences and the Ancient World, School of Human and Social Sciences and Cultural Heritage, University of Padova, Padova, Italy.

*** Retired Scholar.

Correspondence Address: Ernesto Damiani, Department of Biomedical Sciences, School of Medicine, University of Padova, Viale Giuseppe Colombo 3, 35132 Padova, Italy. E-mail: ernesto.damiani@unipd.it. 


\section{INTRODUCTION}

To be struck down, Pierced by sword i' the heart, from a hero's hand!' That I had dreamed.

O mockery of Fate! ...I am foiled, foiled in all, Even in my death. Edmond Rostand, Cyrano de Bergerac, Act V, scene 6

Evidence-based retrospective diagnosis of famous historical figures is a popular genre of History of Medicine. ${ }^{1}$ The availability of the dead body justifies this attractiveness since technological progress allows a better assessment of the cause of death. A recent example is the determination of malignant tertian malaria as the cause of death of Francesco I de' Medici (154I-1587) and his wife Bianca Capello (1548-1587), using an immunological test (MalariaDetect ${ }^{\text {TM }}$ RAPYDTEST $^{\circledR}$, DiaSys, Connecticut, USA) developed for HRP-2 antigen of P. falciparum. ${ }^{2}$

Although the absence of the corpse prevents laboratory investigations of official samples and, consequently, sure conclusions, there is plenty of scientific literature concerning the cause of death of Alexander the Great. ${ }^{3}$ An in-depth meta-analysis of these many papers produced some positive conclusions. ${ }^{4}$ The first is that the vast majority of works $(85.5 \%)$ considered a diagnostic hypothesis possible. ${ }^{5}$ The second is that poisoning, by far the

1 Muramoto, Osamu (2014), Retrospective diagnosis of a famous historical figure: ontological, epistemic, and ethical considerations, Philosophy, Ethics and Humanities in Medicine, $9(10), 1-15$.

2 Fornaciari, Gino and Bianucci, Raffaella (2009), Francesco e Bianca: non fu arsenico - ecco le prove!, Archeologia viva, 138, 78-81.

3 See Damiani, Ernesto (2012). La piccola morte di Alessandro il Grande, Venezia; Marsilio, Appendix I, 20-4, for a list of papers published up to 2012. Additional works are: Retief, Francois P. (2005), The death of Alexander the Great, Acta Theologica, 7 Supplementum, 14-28; Schep, LeoJ., Slaughter, Robin J., Vale, Allister J., Wheatley, Pat (2014), Was the death of Alexander the Great due to poisoning? Was it Veratrum album?, Clinical Toxicology, 52 (1), 72-7; Wiart, Christophe (2014), A note on Conium maculatum L., the plant that defeated Alexander the Great, Clinical Toxicology, 6 (52), 645; Mayor, Adrienne (2014), Alexander the Great: a questionable death, in: Wexler, Philip ed., History of Toxicology and Environmental Health, toxicology in antiquity, vol. 1, Amsterdam; Elsevier, 2014, 52-9; Gamble, Nathan, Bloedow, Edmund F. (2017), A medical-historical examination of the death of Alexander the Great, Journal of Ancient History and Archaeology, 4.3, 1829; Hall, Katherine (2018), Did Alexander the Great Die from Guillain-Barré Syndrome?, Ancient History Bulletin, 32 (3-4), 106-128.

4 The 76 papers listed in Appendix I of Damiani, E. (2012) were considered. Six articles were impossible to attain. Addition of the six additional articles detailed in note 3 resulted in a total of 76 papers.

5 Out of 76, only four works judged impossible to propose a hypothesis, while authors did not take a position in seven cases. Therefore, there were 65 papers spared in which a hypothesis was put forward. Subtraction of nine papers suggesting poisoning gave a final total of 56 papers analysed for natural causes. 
preferred hypothesis by the current journalistic populace, ${ }^{6}$ has received little support from the scientific literature. In fact, only nine papers out of 65 ( $13.9 \%$ of total) have credited this hypothesis. Overall, these two conclusions were foreseeable. On the other hand, the third conclusion is somewhat surprising. In fact, even though the hypothesis privileged by scientific literature is an infectious disease, far too many pathologies have been proposed to explain Alexander's death (see Appendix, Table I).

In our opinion, such a large discrepancy of hypotheses rests on serious mishandling of ancient literary sources. First of all, in many instances, the published papers were 'Letter to the Editor', in which Authors advance a supposition without directly reading ancient authors.

The second and most relevant flaw is deliberately mixing ancient accounts. Authors reporting on Alexander's death are in chronological order: I) the Greek Diodorus of Agyrium, known as Siculus ( $\left.\mathrm{r}^{\mathrm{st}} \mathrm{BC}\right)$, author of Bibliotheca historica; 2) Plutarch of Chaeronea (46/48-I25/127 AD), the renowned author of Parallel lives; 3 ) the Greek Arrian (Lucius Flavius Arrianus) of Nicomedia (ca 95-175 AD), author of the Anabasis of Alexander; 4) the Latin Marcus Iunianus Iustinus (perhaps $2^{\text {nd }} \mathrm{AD}$ ), epitomizer of the Historiae Philippicae of Pompeius Trogus. ${ }^{7}$ The Historiae Alexandri Magni of Latin historian Quintus Curtius Rufus $\left(\mathrm{I}^{\mathrm{st}} \mathrm{AD}\right)$ is useless because of gaps in the passages relating to Alexander's death.

We believe that merging antique sources is an arbitrary procedure for the following reasons. All sources agree only on one fact; that Alexander's disease began after participating at a party. Otherwise, the reading of these sources immediately reveals that they cannot be used as a single, unitary group. On the one hand are the narrations of Plutarch and of Arrian, superimposable to such an extent that merging the two accounts was the standard procedure by most modern historians who have written about Alexander. ${ }^{8}$

6 See Philips, Graham (2004). Alexander the Great: Murder in Babylon, London; Virgin books, Doherty, Paul (2004). The Death of Alexander the Great, London; Constable, and Who Killed Alexander the Great? Atlantic Productions for the Discovery Channel first aired 24 November 2004.

7 Specific passages for Alexander's death are: Diodorus, Bibliotheca historica, XVII, 117, 1-5; Plutarch, Vitae parallelae, Alexander et Caesar, 75-76; Arrian, Alexandrou Anabasis VII, 25-26; Justin, Historiae Philippicae Epitome, XII, 13-15.

8 Sainte Croix, Guillaume-Emmanuel-Joseph Guilhem de Clermont-Lodève, baron de (1775). Examen critique des anciens historiens d'Alexandre-le-Grand, Paris; Henry Grand, Bachelier; Vincent, William (1797). The voyage of Nearchus from the Indus to the Euphrates; collected from the original journals, preserved by Arrian, London; T. Cadell, jun. and W. Davies; Grote, George (1846-1856). History of Greece, London; J. M. Dent \& Co.; New York; E. P. Dutton \& Co.; Littré, Émile (1853), De la science des poisons considérée dans l'histoire, Revue des deux mondes, 4, 665-87. 
On the other hand are the accounts of Diodorus and of Justin, discordant between each other and incompatible with those of Plutarch and Arrian. These differences might originate from the diverse literary sources used by each author. Diodorus and likely Justin too based their respective accounts on the so-called vulgat,${ }^{9}$ whose main source was Cleitarcus of Colophon. ${ }^{10}$

Plutarch and Arrian, however, founded their description of Alexander's final illness on the Royal Ephemerides, an everyday diary written by Alexander's secretaries, Eumenes of Cardia and Diodotus of Eritrea. Alexander's Royal Ephemerides are lost, but with the notable exception of the fragments addressing Alexander's death, precisely transmitted to us by Plutarch and Arrian works. Some scholars considered these fragments a forgery of Alexander's secretaries to support the impression of death by natural causes. ${ }^{11}$ However, the existence of a royal diary, starting with Alexander's father, Philip II (ca $382 \mathrm{BC}-\mathrm{ca} 336 \mathrm{BC}$ ), is widely accepted. ${ }^{12}$ Supporting this notion, there is a notice of the Byzantine lexicon Suda reporting the existence in the first half of the $3^{\text {rd }}$ century BC in the library of Alexandria of a copy of Alexander's Royal Diaries. ${ }^{13}$

However, the strongest criticism against the practice of assembling ancient sources comes from the explicit negation by both Plutarch and Arrian of the principal facts reported by Diodorus. Plutarch specifically denied both

9 Hammond, Nicholas G. (1983). Three historians of Alexander the Great. The so-called Vulgate authors, Diodorus, Justin and Curtius, Cambridge [Cambridgeshire]/ New York; Cambridge University Press.

10 For a detailed study of Diodorus secondary sources, see Waterfield, Robin (2019). Diodorus of Sicily The Library, Books 16-20, Oxford; Oxford University Press, Appendix 1, 537-42.

11 Bosworth, Brian A. (1971), The death of Alexander the Great: rumour and propaganda, Classical Quarterly, 21 (1), 112-36. Bosworth proposed that these passages were inspired by Alexander's assassins to corroborate the opinion of death by natural causes. Regardless of the correctness of Bosworth's hypothesis, which is a problem for classical philologists, he actually recognized that the narration of the Royal Ephemerides described a death from natural causes. For a convincing refutation of Bosworth's hypothesis, see Hammond, Nicholas G. (1988), The Royal Journal of Alexander, Historia, 37, 129-50. For a detailed study of Arrian and his historical production see Bosworth, Brian A. (1980). A Historical Commentary on Arrian's History of Alexander, Oxford: Clarendon Press; New YorkOxford University Press.

12 Pearson, Lionel (1960). The lost histories of Alexander the Great, New York; American Philological Association, 434.

13 Adler, Ada (1928-1938). Suidae Lexicon, sigma 1179, Leipzig; Teubner. It is generally said that this copy was Alexander's one, taken by Ptolemy to Egypt along with Alexander's mummy (Pausanias, Periegesis, 1.6.3). However, there is no evidence whatsoever supporting this belief, see Baynham, Elizabeth (2003), The ancient evidence for Alexander the Great, in Roisman, Joseph ed., Brill's companion to Alexander the Great, Leiden/Boston; Brill, 2003, 3-30. 
the story of the sudden stab of pain and the episode of the bow of Herakles. ${ }^{14}$ Arrian reported the story of the sudden stab of pain as a variant version, clearly stating that he did not believe it..$^{15}$

Finally, from a medical standpoint, the narrations of Alexander's final illness are too different. Diodorus related the death of Alexander in a few lines, without providing any timescale. ${ }^{16}$ His narration completely lacked signs and symptoms with the exception of an acute pain occurring after Alexander drank from the 'bowl of Heracles'. He did not report fever and had Alexander conscious until the very last moment. Lastly, Diodorus is the only source saying that Alexander was assisted by physicians. Justin described a disease lasting at least six days, without fever and characterized by the sudden occurrence of stabbing pain and nothing else. ${ }^{17}$ Whereas Diodorus reported that Alexander was capable of speaking until the last moment before his death, Justin wrote that the sick King was unable to speak on the sixth day of his illness. Justin is the only author openly supporting the poisoning.

In sharp contrast, the narrations of Plutarch and of Arrian contain plenty of details useful for clinical interpretations (see Appendix, Table 2). They both described thirteen days of illness characterized by a fever but without additional symptoms, such as dyspnoea, cough with or without sputum, vomit, diarrhoea, the pain of whatever type, or cutaneous alterations either of the colour (bluish indicative of cyanosis, yellowish suggestive of jaundice) or of the appearance (erythema, macules, papules etc.). In addition to fever, there

14 Plutarch, Parallel lives, Alex. 75, 5, "and here, after drinking all the next day, he began to have a fever. This did not come upon him after he had quaffed a "bowl of Heracles," nor after he had been seized with a sudden pain in the back as though smitten with a spear; these particulars certain writers felt obliged to give, and so, as it were, invented in tragic fashion a moving finale for a great action.", Perrin, Bernadotte (1914). Plutarch: Lives, vol. VII: Demosthenes and Cicero, Alexander and Cesar, London; William Heinemann; New York; The MacMillan Co., quotation on 433.

15 Arrian, Anabasis, VII, 27, "I am aware that many other particulars have been related by historians concerning Alexander's death [...]They say that Alexander was seized with an acute paroxysm of pain over the wine-cup, on feeling which he retired from the drinking bout [...] These statements I have recorded rather that I may not seem to be ignorant that they have been made, than because I consider them worthy of credence or even of narration.", Chinnock, Edward J. (1884). The Anabasis of Alexander, London; Hodder and Stoughton, quotation on 421-22

16 Diodorus, Bibliotheca historica, XVII, 117, 1-5, English translation by Oldfather, Charles H. (1963). Diodorus Siculus. Diodorus of Sicily in Twelve Volumes, Cambridge, Mass.; Harvard University Press; London; William Heinemann, Ltd., vol. 8, 467-468.

17 Justin, Epitome of the Philippic History of Pompeius Trogus, XII, 13-15, 8, English translation by Watson, John S. (1853). Justin, Cornelius Nepos and Eutropius, literally translated with notes and a general index, London; Henry G. Bohn, York Street, Covent Garden, $117-20$. 
was a progressive impairment of mobility, loss of voice at late stages and maybe a deterioration of consciousness up to the second week of the disease.

Therefore, based on all these considerations, we think that one can legitimately use either the relations of Plutarch and of Arrian assembled together, or the narration of Diodorus or of Justin, but not of Diodorus and Justin collected.

\section{THE TYPHOID FEVER HYPOTHESIS}

Typhoid fever has already been hypothesized as the cause of Alexander's death. ${ }^{18}$ Epidemiology of the disease strongly supports this possibility. In fact, typhoid fever has always been one of the commonest worldwide bacterial infections, with a very high lethality irrespective of age and comorbidities. The high prevalence of typhoid fever was particularly true of armies throughout much of history, the last major epidemics occurring during the Spanish-American War (I898) and the Anglo-Boer War (I899-I902). ${ }^{19}$ Epidemics of typhoid fever during campaigning were due to poor sanitation practices that included drinking sewage polluted water from waterways ${ }^{20}$ and eating food contaminated by flies. ${ }^{21}$ The epidemics of typhoid fever ended in I9II when the US Army introduced mandatory vaccination for military personnel during campaigning. ${ }^{22}$

While epidemics are caused by contaminated water, isolated cases are transmitted by asymptomatic carriers, who harbour the bacteria in the gall bladder after recovery and directly contaminate food or water by dirty hands. ${ }^{23}$

18 Cunha, Burke A. (2004), The death of Alexander the Great: malaria or typhoid fever? Infectious Diseases Clinics of North America, 18 (1), 53-63; Adler, Richard, Mara, Elise (2016). Typhoid Fever: A History, Jefferson, NC; McFarland, 25-33.

19 Cirillo, Vincent J. (2014), Arthur Conan Doyle (1859-1930): Physician during the typhoid epidemic in the Anglo-Boer War (1899-1902), Journal of Medical Biography, 22, 2-8.

20 Lim, Matthew, Murphy, Gerald, Calloway, Margaret and Tribble, David (2005), History of U.S. military contribution to the study of diarrheal diseases, Military Medicine, 170 (supplementum 4), 30-8.

21 Cirillo, Vincent J. (2006), "Winged sponges": houseflies as carriers of typhoid fever in 19th-and early 20th-century military camps, Perspectives in Biology and Medicine, 49 (1), $52-63$.

22 Grabenstein, John D., Pittman, Phillip R., Greenwood, John T., Engler, Renata J.M. (2006), Immunization to protect the US Armed Forces: heritage, current practice and prospects, Epidemiological Reviews, 28 (1), 3-26.

23 The first and most famous case of the asymptomatic carrier was that of the cook Mary Mallon, see Marineli, Filio, Tsoucalas, Gregory, Karamanou, Marianna and Androutsos, George (2013), Mary Mallon (1869-1938) and the history of typhoid fever, Annals in Gastroenterology, 26 (2), 132-34. 
S. typhi definitely existed during Alexander's age. ${ }^{24}$ In fact, typhoid fever might be the possible cause of the so-called Plague of Athens occurring during the first year of the Peloponnesian War (43I-404 BC). ${ }^{25}$ For all these reasons, the likelihood that Alexander died of this disease rather than of other diseases that are rarer (e.g. Guillain Barrè syndrome) ${ }^{26}$ or much less virulent (e.g. West Nile encephalitis) ${ }^{27}$ would be far greater. In the latter case, the very existence of the virus at the time of Alexander has been questioned. ${ }^{28}$ As far as P. falciparum malaria is concerned, it presents a high death risk only in selected populations, such as immunodepressed, individual children under 5 years of age and pregnant women. ${ }^{29}$

\section{EVIDENCE IN SUPPORT OF TYPHOID FEVER HYPOTHESIS: PRESENCE OF REMITTENT FEVER}

The typhoid fever hypothesis is based on Plutarch's and Arrian's descriptions. This choice comes from the necessity of having signs and symptoms in order to address a clinical case. Plutarch's and Arrian's narrations contain plenty of information supporting diagnostic interpretations. Conversely, the descriptions of Diodorus and Justin simply do not contain enough information.

Typhoid fever has two basic signs, a remittent fever and stupor, on which the diagnosis rests. In our opinion, both signs can be deduced from the descriptions of Plutarch and Arrian.

Fever can be classified in several types based on thermography, i.e. the trend of fever as a function of time. ${ }^{30} \mathrm{~A}$ fever is called intermittent, when the pyrogenic phase (i.e. the stage of development of a fever), peaks in a few hours.

24 Roumagnac, Philippe, Weill, François-Xavier, Dolecek, Christiane, Baker, Stephen, Brisse, Sylvain et. al (2006), Evolutionary history of Salmonella typhi, Science, 314 (5803), 1301-304.

25 Papagrigorakis, Manolis J., Yapijakis, Christos, Synodinos,Philippos N. and Baziotopoulou-Valavani, Effie (2006), DNA examination of ancient dental pulp incriminates typhoid fever as a probable cause of the Plague of Athens, International Journal of Infectious Diseases, 10 (3), 206-14.

26 Hall, Katherine (2018), 106.

27 Gray, Timothy J. and Webb, Cameron E. (2014), A review of the epidemiological and clinical aspects of West Nile virus, International Journal of General Medicine, 7, 193-203.

28 Galli, Massimo, Bernini, Flavia, and Zehender, Gianguglielmo (2004), Letter to the Editor: Alexander the Great and West Nile virus encephalitis, Emerging Infectious Diseases, 10 (7), 1330-32.

29 Mphaka, Makgomo R., Moshime, Mpho, Tsilo, Lipontseng C. and Reddy, Carl (2019), Risk Factors Associated With Malaria Mortality in Tshwane District, South Africa, Fortune Journal of Health Science, 2, (2), 30-9.

30 Wunderlich, Carl A. (1868). Das Verhalten der Eigenwärme in Krankheiten, Leipzig; Verlag von Otto Wigand. 
Because of this, it is always associated with strong feelings of chilliness with shivering and chattering of the teeth. The fastigium phase (i.e. the stage in which fever has reached its peak), is short and is suddenly followed by defervescence that is complete in a matter of hours (crisis) and is accompanied by copious sweating. When projected on a chart, intermittent fever presents with daily spikes typically separated by intervals of apyrexia. Intermittent fever is typical of malaria. The different forms are differentiated by the duration of the apy retic interval, one day (tertian malaria) or two days (quartan malaria). Other infectious diseases, such as smallpox, bacterial pneumonia, typhus, scarlatina, meningitis, are characterized by intermittent fevers, but a short pyrogenic stage never occurs in typhoid fever.

On the other hand, a fever is remittent, when the pyrogenic phase is protracted and is characterized by fluctuations in the temperature of $\mathrm{I}^{\circ} \mathrm{C}$ or more, but always remaining above normal. In other words, the fever rises slowly but continuously in the form of sawtooth without periods of apyrexia. French medical literature described this pattern of a rising temperature as ascension lente à oscillations ascendantes, differentiating it from fevers characterized by the marche suraiguë, typical of intermittent malarial fevers. ${ }^{31}$ Wunderlich, the father of clinical thermography, described the pattern of remittent fever in this way:

"Forms of disease with protracted pyrogenic stage. The rise of temperature generally happens thus: it begins to ascend in the evening, in the morning hours it moderates again, to rise again more the following evening. It may thus happen that the normal temperature is again reached in the morning of the second day. [...] In this type [of fever] the initial stage lasts three of four days, but seldom more than a week [...] This type occurs most constantly in typhoid fever, and so much that the diagnosis can be safely based upon the initial stage only." 32

Since this classical description, the thermography of typhoid fever has been called the curve of Wunderlich. In untreated cases in which the patient survived, the disease lasted four weeks. In the first week, the temperature increased in a slow stepwise fashion. In the fastigium phase lasting two weeks, the temperature was constantly high with a remittent or non-continuous

31 Jaccoud, Sigismond (1877). Traitée de pathologie interne, Paris; V. Adrien Delahaye et C., Libraires-Éditeurs, vol. 186.

32 Wunderlich, Carl A. (1871). On the Temperature in diseases: a manual of medical thermometry. Translated by W. Bathurst Woodman, London; The New Sydenham Society, 246. 
course. Finally, defervescence occurred gradually (lysis) in the final week. Because of the gradual ascension and of the slow defervescence, the respective clinical correlates of shivering and sweating were commonly absent. At the end of the nineteenth century, diagnosis of typhoid fever was based on its typical thermography. ${ }^{33}$

Inspection of the trend detailed by Plutarch and Arrian clearly classifies Alexander's fever as a remittent one (Appendix, Table 3). His fever displayed a slow pattern of ascension lasting several days. Initially, there was an outburst of fever during the night (I7 Daesius). Fever became continuous at night after two more days (I9 Daesius), finally becoming constant during both night and day starting from 2I Daesius. The fever grew to be very high on 24 Daesius, remaining continuously very high to the last day for which we have a hint of fever.

French medical literature had identified the progressively increasing character of Alexander's fever already in $19^{\text {th }}$ century. In 1798 , the French physician Jean François Jacques Roussille de Chamseru (I749-I823) used the periphrasis of marche de la pyrexie to indicate the thermography of Alexander's fever, exhibiting paroxysms becoming progressively longer and closer until fever became continuous. ${ }^{34}$ Later it was Émile Littré's turn to highlight peculiarities of Alexander's fever: "Ce qui est caractéristique, ce sont les apyrexies du commencement. Una fièvre qui dure onze jours, qui offre à son début des intermissions et qui finit par devenir continue [...] ces fièvres ont désignées sous le nom de pseudo-continues." ${ }^{35}$ In the Medical dictionary he edited, Littré defined pseudo-continue fevers as "fièvres rémittentes, qui prennent le caractère continu." 36 Therefore, for Littré, Alexander's fever was initially a remittent fever becoming continuous in several days.

Based on these considerations, we are led to conclude that the fever described by Plutarch and Arrian corresponds to the first two weeks of Wünderlich's curve. One common objection to the typhoid fever hypothesis is the lack of abdominal signs in Plutarch and Arrian descriptions. This is

33 Strümpell, Adolf (1887). A textbook of Medicine for students and practitioners, New York; D. Appleton and Company, 5.

34 Roussille-Chamseru, Jean François Jacques (1798), Observations médicales, extraites d'auteurs non médecins, appliquées à la description des fièvres subintrantes, et devant faire partie d'un plus grand travail, Mémoires de la Société Médicale d'émulation, 1, 14-23.

35 Littré, E. (1853), 678.

36 Nysten, P.H. Littré, E., Robin Ch. (1855). Dictionnaire de médecine, de chirurgie, de pharmacie des sciences accessories et de vétérinarie de P.H. Nysten, Ch. Robin, Paris; Chez J.-B. Baillière, 533. 
easily explained, on the basis of pathogenesis of ulcerations of the bowel leading to haemorrhagic diarrhoea. The damage is due to a delayed-hypersensitive type reaction requiring 2-3 weeks to develop. Alexander died on the thirteenth day of illness. In typhoid fever, death occurring in the first two weeks is due to endotoxic shock. Therefore, the absence of abdominal signs in Alexander's clinical picture is fully consistent with the time-course of typhoid fever.

\section{Clinical evidence for the Presence of STUPOR}

Typhoid fever is called like this because fever is accompanied by a state of cloudiness of consciousness characterized by deep somnolence and depression of psychomotricity, with a compromised ability to react to environmental stimuli such as pain or questions. The altered state of consciousness characterizing typhoid fever is called stupor, the Latin translation of the Greek word $\tau$ v́pos meaning fog, vapor. ${ }^{37}$ Therefore, the typhoid patient is in a foggy or clouded state. Stupor differs from a real coma since the patient can be aroused to consciousness by vigorous and repeated stimuli, whereas a comatose patient is unresponsive and cannot be aroused. The demonstration of stupor in the narrations of Plutarch and Arrian has been elusive thus far. Here, for the first time, we report a clue suggesting that Alexander was stuporous in the final days of illness.

Royal Diaries narrate that, in advanced disease, Alexander became speechless. In both Plutarch's and Arrian's narrations, the word ö $\varphi \omega v o \varsigma$ is used. According to Plutarch, Alexander was already ö $\varphi \omega v o \varsigma$ in the evening

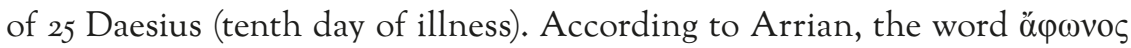
is used on 26 Daesius, when describing the procession of Macedonian soldiers in front of dying Alexander, who reacted only with slight movements of eyes and head, because he was speechless ( descriptions contain the key clue. In fact, although devoid of voice is the usual translation, actually, $\alpha \varphi^{\prime} \omega v o \zeta$ is a technical term belonging to the lexicon of the pathology of Greek medicine, as testified by Caelius Aurelianus. ${ }^{38}$

Caelius Aurelianus is a Latin physician (late $4^{\text {th }} /$ early $5^{\text {th }}$ AD) known as the author of De morbis acutis et chronicis libri VIII, a treatise on acute (Celeres

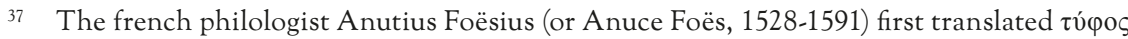
with stupor attonitus, see Ongaro,Giuseppe (2008), Dal typhos all'ileotifo, in Storie di Medici e di Medicina, Padova; Cleup, 2008, 17-36.

38 Stok, Fabio (2000), Note sul lessico della patologia in Celio Aureliano', in Sconocchia, Sergio, Toneatto, Lucio eds., Lingue tecniche del greco e del latino, III. Atti del III Seminario internazionale sulla letteratura scientifica e tecnica greca e latina, Bologna; Patron, 2000, 147-67. 
passiones) and chronic (Tardae passiones) diseases. ${ }^{39}$ Actually, this essay is the

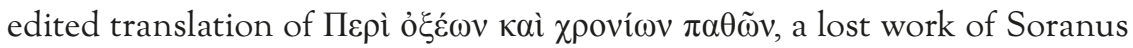
of Ephesus (98-138), the most influential physician of the Methodic school to which Caelius Aurelianus himself belonged. Caelius Aurelianus' work, therefore, is most important because he transmitted the Greek medical tradition. ${ }^{40}$

In the first nine chapters of the second book of Celeres passiones, Caelius Aurelianus discusses a specific disease, called lethargus, characterized by a state of unawareness and inaction. ${ }^{41}$ Based on Soranus' authority, Caelius Aurelianus defines lethargus as a disease in which a state of drowsiness follows an acute fever, ${ }^{42}$ both signs being necessary for diagnosing the malady. ${ }^{43}$ Caelius Aurelianus specifies that the fever characterizing lethargus may be continuous or interspersed with a phase of remission (dimissionibus intercapedinata). Émile Littré translated the Latin periphrasis as remittent fever. ${ }^{44}$ According to Caelius Aurelianus, therefore, letharghus is a specific disease characterized by a diagnostic triad of depression of consciousness, somnolence and acute fever. Without these signs, lethargus cannot be diagnosed. ${ }^{45}$

Today, the term lethargy no longer indicates a specific illness but rather denotes a condition of hypersomnia from which the patient can be awoken by mild stimuli. It is the least serious of a continuously progressing spectrum of alterations of the level of consciousness, and in time is followed by stupor and waking coma. ${ }^{46}$ Lethargy and stupor are generally the consequence of infectious disease, such as typhoid fever or typhus, and reflect neurological

39 For the English translation, see Drabkin, Israel Edward (1950). Caelius Aurelianus. On acute Diseases and chronic Diseases, Chicago; University of Chicago Press. For the recent german edition, see Bendz, Gerhard, Corpus Medicorum Latinorum vol. VI 1(1990. 1993), Caelii Aureliani Celerum Passionum libri III - Tardarum passionum libri V, edidit G. Bendz, in linguam Germanicam transtulit I. Pape, Pars I: Cel. pass. lib. I-III; Tard. pass. lib. I-II; Pars II: Tard. pass. lib. III-V, Berlin, thereafter abbreviated as CML VI 1.

40 Dysert, Anna (2007), Capturing Medical Tradition: Caelius Aurelianus' On Acute Diseases, Hirundo: The McGill Journal of Classical Studies, 5, 161-73.

41 Celeres passiones, II, 1, 1 [CML VI 1.1, 130, 5-8].

42 Celeres passiones, II, 1, 8 [CML VI 1.1, p. 134, 23-24].

43 Celeres passiones, II, 3, 13 [CML VI 1.1, p. 138, 5-7].

44 Littré, Émile (1840), A quali malattie si devono riferire le storie delle malattie che Ippocrate ha collocato fra le Epidemie, che debbasi intendere per causo, per frenite e per letargo, Giornale delle Scienze Medico-Chirurgiche, LXXIII, 35.

45 Celeres passiones, II, 3, 13[CML VI 1.1, p. 138, 9-12].

46 Waking coma is defined as a state of alteration of consciousness in which the patient can withdraw spontaneously from the source of pain without exhibiting any spontaneous motor activity. 
damages. ${ }^{47}$ The side-by-side comparison of the description of lethargus made by Caelius Aurelianus with that of waking coma taken from a modern treatise of Internal Medicine clearly demonstrates that the two conditions are one and the same:

"Lethargy: We recognize a case of lethargy from the impairment and dullness of the sense, stupor [...] First, there is the sunken stupor, an indeterminate state that resembles sleep. The patient, when summoned, may easily shake this off, and, on being questioned, make answer, not immediately, to be sure, but after a while. [...] In speaking, he will forget what has been said; he will confuse and garble the order of letters and will be unable to pronounce his words. [...] As the disease increases, [increases] inability to concentrate, so much so that only if he is pricked or called loudly can he be aroused, and even then he merely moves and contracts his lips slightly and sinks again into his stupor."48

"Waking coma: The patient presents hypersomnia from which he can momentarily recover thanks to intense sensory stimuli. In these brief moments of clarity of conscience, the patient answers monosyllabic to questions, sometimes however being confused so that he does not understand correctly what he is questioned. He reacts slowly and incompletely to simple orders." ${ }^{49}$

In chapter X of the same book II, Caelius Aurelianus continues to describe another disease, similar to lethargia that is called $\kappa \alpha \tau \dot{\lambda} \lambda \eta \psi 1 \varsigma$ by the Greeks. Caelius Aurelianus translates this in Latinas as apprehensio or oppressio. ${ }^{50}$ The latter term is translated in modern editions with stupor. ${ }^{51}$. However, what makes the link between $\kappa \alpha \tau \alpha ́ \lambda \eta \psi 1 \zeta$ and Alexander's disease so important is Caelius Aurelianus' clarification that both Hippocrates in his Aphorisms and Diocles of Carystus ${ }^{52}$ in his book Prognostic called this af-

47 Tardieu, Guy (1942), Le typhus. Étude physio-pathologique de l'atteinte du diencéphale au cours de la fièvre typhoïde, Presse médicale, 50 (7-8), 75-8.

48 Celeres passiones, II, 3, 14-16 [CML VI 1.1, pp. 138, 9-140.9], translated by Drabkin, Israel Edward (1950), 129-31.

49 Teodori, Ugo (1976). Trattato di Patologia medica, Roma; S.E.U., 3680, (English translation by E.D.)

50 Celeres passiones, II, 10, 56 [CML VI 1.1, p. 164, 18-20]. According to Stok, F. (2000), 159-160, apprehensio relates mainly to sensory, while oppressio concerns prevalently physical and somatic qualities. Caelius Aurelianus often substituted oppressio with pressura, i.e. deep somnolence

51 See Drabkin, I.E. (1950), 159.

52 Diocles of Carystus was a Greek physician of $4^{\text {th }}$ B. C., see Van der Eijk, Philip J. (2000). Diocles of Carystus A collection of the fragments with translation and commentary, Leiden/Boston/Koln; Brill. Amention to Prognostic is also made in a section of Passiones tardes, IV, 8, 112. 
fection $\dot{\alpha} \varphi \omega v i \alpha^{53}$ According to Caelius Aurelianus, therefore, $\dot{\alpha} \varphi \omega v i ́ \alpha$ does

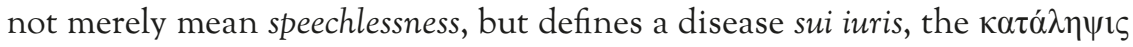
of Hippocrates. ${ }^{54}$

Caelius Aurelianus warns that, because of similarities between the clin-

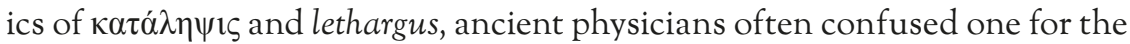
other. ${ }^{55}$ As a further point of a relationship, Caelius Aurelianus added that $\kappa \alpha \tau \dot{\lambda} \lambda \eta \psi 1 \varsigma$ might evolve in lethargus. ${ }^{56}$

Caelius Aurelianus described additional signs displayed by patients af-

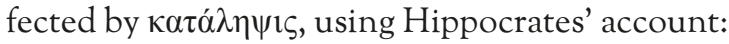

"Hippocrates says that people who suddenly lose their speech (whom he called aphônoi) do so because of the veins [...]. Many of these people subsequently get the following symptoms: the face became red, the eyes are fixed without any movement of the eyelids, the hands are carelessly spreadeagled and thrown apart, they gnash their teeth, there is a spasm of the limbs and convulsive movement of the jaw muscles called by Greeks siagonitai." ${ }^{157}$

Here, we identify the original Hippocratic passage from the Regimen in acute diseases quoted by Caelius Aurelianus: 'When a person suddenly loses his speech, in connection with obstruction of the veins [...] Such cases are mostly attended with the following symptoms: redness of the face, eyes fixed, hands distended, grinding of the teeth, palpitations, jaws fixed [...].58

Actually, dyskinesias described by Hippocrates are not specific of $\kappa \alpha \tau \dot{\alpha} \lambda \eta \psi 1 \varsigma$ since Caelius Aurelianus says that they are also present in the lethargic patient. ${ }^{59}$ However, what is most remarkable about Hippocrates'

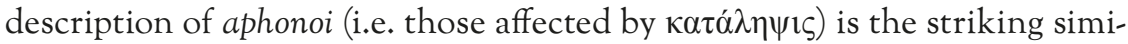

53 Celeres passiones, II, 10, 56 [CML VI 1.1, p. 164, 20-22].

54 Stok, F. (2000), 158.

55 Celeres passiones, II, 10, 57 [CML VI 1.1, p. 166, 4-5].

56 Celeres passiones, II, 10, 73 [CML VI 1.1, p. 174, 30-33].

57 Celeres passiones, II, 10, 59 [CML VI 1.1, p. 166, 20-27], English translation by Drabkin, I. E. (1950), 161.

58 Hippocrates, De victu acutorum spur in Littré, Émile (1839-1861), Euvres complètes d'Hippocrate, Paris chez J.-B. Baillière 1839-1861, (repr. Amsterdam, Hakkert, 1961-1962), thereafter abbreviated as Littré, English translation by Adams, Francis (1849). The genuine works of Hippocrates, London; The Sydenham Society, vol. 1, 315-316. Drabkin had already noticed the presence in Caelius Aurelianus' treatises of long quotations from Hippocratic works, particularly from Regimen in acute diseases, see Drabkin, Israel Edward (1945), Notes on the text of Caelius Aurelianus, Transactions and Proceeding of the American Philological Association, 76, 299-320, note 5.

59 Celeres passiones, II, 3, 15 [CML VI 1.1, p. 138, 22-24], English translation "Though the body is not faint, he cannot keep his hands outstretched; his limbs tremble and quiver," Drabkin, I.E. (1950), 131. 
larity with modern descriptions of typhoid state ${ }^{60}$ made by Sir William Osler (r849-19r9) and Adolf Strümpell (r853-1925) (Appendix, Table 4).

The $\dot{\alpha} \varphi \omega v i \alpha$ of Hippocrates and the typhoid state of Osler and Strümpell, then, share impairment of consciousness and dyskinesias of limbs and face. The staring, apathetic face with fixed eyes is called facies tifosa. Subsultus tendinum is the visible muscular twitching of the back of hands. The picking at imaginary objects is called flocillation, whereas the picking of the bedclothes is called carphology. Overall, from this, it is possible to conclude that the disease called $\dot{\alpha} \varphi \omega v i \alpha$ by Hippocrates and $\kappa \alpha \tau \alpha \dot{\lambda} \lambda \eta \psi \iota \varsigma$ by Caelius Aurelianus was a febrile illness, associated with intellectual enfeeblement, apathy and somnolence, i.e. stupor, and with dyskinesias of face and limbs, a clinical presentation superimposable to that of the typhoid state.

Why did Hippocrates use the symptom ḋ $\varphi \omega v i \alpha$ to name $\kappa \alpha \tau \dot{\alpha} \lambda \eta \psi 1 \zeta$ ? We learn this from Galen of Pergamon (130 ca-200 ca AD). In his comments to Hippocrates' Aphorisms, ${ }^{61}$ Galen twice states that it was customary for Hippocrates to name a disease from a distinctive symptom. ${ }^{62}$ For this reason, Galen reports that when Hippocrates brought up the word ö $\varphi \omega v o r$, he was referring to those sick individuals that together with the loss of the voice were losing both the ability to move spontaneously and the consciousness. ${ }^{63}$ Therefore, in Aphorisms according to Hippocrates ö $\varphi \omega v o r$ were: 1) drunk individuals in a state of carus, (i.e. in an ethylic coma) ${ }^{64} 2$ ) victims of apoplectic stroke (i.e. ictus); ${ }^{65}$ ) individuals who suffered a concussion. ${ }^{66}$ These pathological conditions shared altered consciousness and motility following cerebral damage, be it toxic, haemorrhagic or traumatic in nature. Because of brain damage, these patients were all equally ö $\varphi \omega v o u$. The term $\ddot{\alpha} \varphi \omega v o \zeta$ is also found with this technical meaning, evocative of altered consciousness in Epidemics, ${ }^{67}$ where Hippocrates defines $\ddot{\alpha} \varphi \omega v o \zeta$ as those in a state of total unconsciousness for one day and one night, following fainting. ${ }^{68}$

60 Verghese, Abraham (1985), The Typhoid State revisited, Am J Med, 79, (3), 370-72.

61 Galen, In Hippocratis Aphorismos Commentarii I-VIII, in Kühn, Karl Gottlob (1964-1965), in Claudi Galeni opera omnia, Editionem curavit D. Carolus Gottlob Kühn, vol. I-XX, [Lipsiae, 1821-1833 (= Hildesheim; Olms, 1964-1965)], thereafter abbreviated as Kühn.

62 Galen, In Hippocratis Aphorismos Commentarii V aph.5 (XVIIb, 788, Kühn); VII aph. 58 (XVIIIa, 170 Kühn).

63 Galen, In Hippocratis aphorismos commentarii VI aph. 51 (XVIIIa, 87, Kühn).

64 Galen, In Hippocratis aphorismos commentarii V aph. 5 (XVIIb, 788, Kühn).

65 Idem, see note 63.

66 Galen, In Hippocratis aphorismos commentarii VII aph. 58 (XVIIIa, 170-171, Kühn).

67 Épidémiae, VII, 108 in Littré, vol. 5, 458.

68 Lo Presti, Roberto (2009), "Le rappresentazioni del corpo "anaisthētos" nel Corpus Hippocraticum: una 'via negativa' verso la conoscenza”, I Quaderni del ramo d'oro, online 2, (92), 51-91. 
Actually, this Hippocratic connotation of the term aphonia seems to have been lost in recent times. In fact, prior literature knew well that in Greek medicine the term aphonia indicated much more than the loss of a voice. Rodrigo Fonseca (died 1622), a famous Portuguese physician who taught Internal Medicine at the University of Padua, in his Commentaria to Hippocratic Aphorisms clearly stated that "Quod aphonia, seu obmutescentia non solum vocis privationem hic, sed omnis motus, et sensus missionem significat. ${ }^{169}$ Later, in 1702 the Franciscan monk Vincenzo Maria Coronelli (1650-1718) in his Biblioteca Universale sacro-profana grouped epilepsy, apoplexy, catalepsy, and syncope under the heading of Aphonia, because of the loss of voice in each of these illnesses. ${ }^{70}$ Furthermore, in 1722 Johann Konrad Amman (1669-1724), a celebrated Swiss editor of Caelius Aurelianus' work,

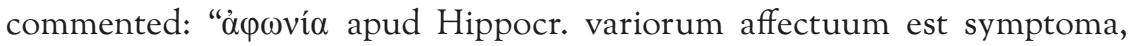
ebrietatis, ictus, febris, etc." "71 Finally, a Medical Dictionary of the late-1700 confirmed, "Hippocrates calls aphoni those who labour under a caros," and that aphonia was used by Hippocrates "to express those who with the loss of voice lose all voluntary motion; as in epilepsies, apoplexies, a syncope etc."72

Investigating the meanings of silence in Corpus Hippocraticum, Silvia Montiglio noted "the frequency with which the Hippocratic writings record one's loss of speech and voice in the progression of various types of illnesses, and especially at their terminal stage." 73 This would suggest that the term ă $\varphi \omega v o \varsigma$ might also embody a prognostic value. Indeed, in three fatal cases described in Epidemics, ${ }^{74}$ Hippocrates used the word $\ddot{\alpha} \varphi \omega v o s$ immediately prior to death. On the contrary, in another case, just before the terminal stages of the sickness, Hippocrates precedes the term ö $\varphi \omega v o s$ from the word ävavdo (usually translated as speechless). ${ }^{75}$ In his comment to this pas-

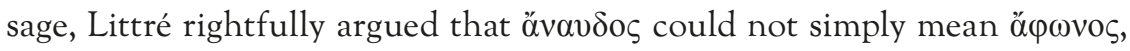

69 Roderico a Fonseca (1678). Commentaria in septem libros Aphorismorum Hippocratis, Patavii; Iacobi de Cadorinis, Aphorismus LVIII, 349-350.

70 Coronelli, Fra' Vincenzo (1702). Biblioteca universale sacro-profana, antico-moderna, Venezia; Tivani, 52-3.

71 Amman, Johann Conradus (1722). Caelii Aureliani Siccensis De Morbis Acutis \& Chronicis Libri VIII, Amstelaedami; Ex Officina Wetsteniana, 96, note 3.

72 Motherby, George (1775). A new Medical Dictionary, London; Johnson \& Robinson, ad vocem Aphoni and Aphonia.

73 Montiglio, Silvia (2000). Silence in the land of logos, Princeton; Princeton University Press, 228.

74 They are the case of Philiscus, described in Epidemics, I, 3 [Littré, II, 682-685; English edition, Jones, William Henry Samuel, (1959). Hippocrates, London; Loeb Classical Library, vol. I, 187, thereafter abbreviated as Jones]; the case of Silenus [Littré, II, 684-689; Jones, I, 187-191], and the case of the wife of Philinus [Littré, II, 691-695; Jones, I, 193-195].

75 Épidémiae, III, 3[Littré, III, 112-117; Jones, I, 263-266]. 
since the two terms are in sequence. ${ }^{76}$ The sick, therefore, was $\alpha{ }^{\prime} \alpha v \delta$ o $\zeta$ and

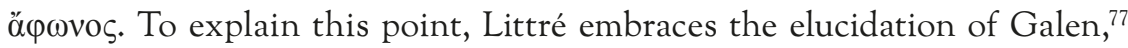

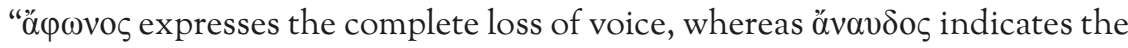
loss of the faculty to articulate the speech [....] This explanation of Galen, that I believe should be adopted, establishes a ranking of meaning between

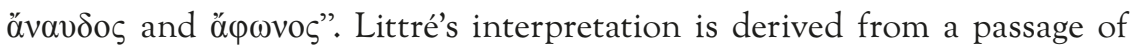

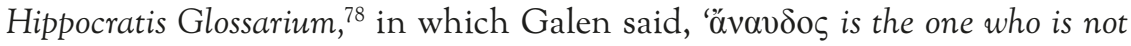
able to speak correctly and appropriately' (bene et apte is the Latin translation

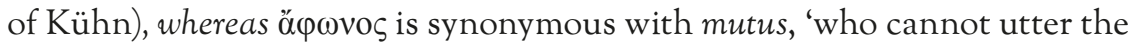
voice' (qui vocem emittere non potest, in Kühn's edition). In modern phraseology, different meanings of the two words would reflect different pathogenetic mechanisms. Pathogenesis of $\alpha \varphi \omega v i ́ \alpha$ is of central origin (i.e. caused by brain damage), whereas pathogenesis of $\dot{\alpha} v \alpha v \delta i ́ \alpha$ is of peripheral origin (i.e. caused by damage to the vocal system). In other words, the Hippocratic

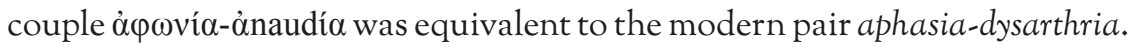
Therefore, the use of á $\varphi \omega v o \varsigma$ in terminal stages of disease would mean poor prognosis. ${ }^{79}$ In fact, in the above-mentioned case, Hippocrates referred to

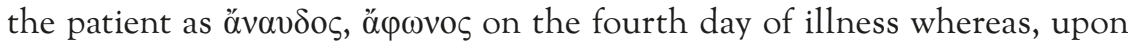
progression to the tenth day when the patient was comatose, he ascribed the word ö $\varphi \omega v o \varsigma$ to the patient.

In his narration of Alexander's death, Arrian uses the same sequence of

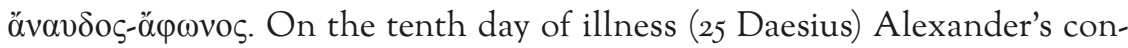
ditions are described as very severe, and at a meeting with his generals, the

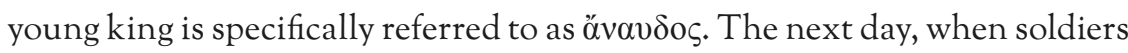
are filing past him, Alexander has become ä $\varphi \omega v o s$. Based on previous considerations, the sequential use in this context of the two terms would suggest a worsening of Alexander's clinical picture. That being the case, the development of $\alpha \varphi \omega v i ́ \alpha$ on the evening of 26 Daesius would easily explain why "the Macedonians made up their minds that Alexander was dead." 80

\footnotetext{
Épidémiae, III, 3 [Littré, III, 114, note 8].

"Galien propose une autre explication, et qui, dans le fait, parait bien préférable [...] $\alpha$ ö $\omega v o \varsigma$ exprime la perte absolue de la voix, et ővovooৎ la perte de la faculté d'articuler, la perte de la parole [...] Cette explication de Galien, qui me parait devoirêtre adoptée, établit une gra-

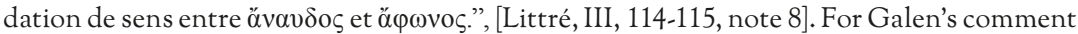
see Epidemiae, III, 114, note 8, comment to case LXXIV [XVIIa, 751-759, Kühn]. Galen, Linguarum seu dictionum exoletarum Hippocratis explication [XIX, 79, Kühn).

79 Byl, Simon (2006), Le délire hippocratique dans son contexte, Revue Belge de Philologie et d'Hist, 84, 5-24, "Le patient (...) il est atteint d'aphonie (à $\varphi \omega n i ́ \eta-\alpha ̈ \varphi \omega v o \varsigma)$ qui n'est nullement l'extinction de voix mais est un signe extrêmement funeste", quotation on 10.

Plutarch, Parallel lives, Alex. 76,8.
} 
One might object that inference of the Hippocratic meaning of $\ddot{\alpha} \varphi \omega v o \varsigma$ from the reported passages of the Royal Diaries is unwarranted. However, it might be argued that Greek medicine was well represented at the Macedonian court, ${ }^{81}$ maybe by Hippocrates himself..$^{82}$ The interest of the Macedonian court in Hippocratic medicine is further suggested by the presence of Nicomachus, Aristotle's father, the court physician of Amintas III. Aristotle himself was particularly interested in medicine and considered studying medicine part of the general education of cultivated Greek men. ${ }^{83}$ Since Aristotle was the tutor of Alexander, it is not surprising that the young Macedonian king was devoted to the study and practice of Hippocratic medicine ${ }^{84}$ as also supported by recent studies ${ }^{85}$ For all these reasons, it looks very unlikely that the drafter of the Royal Diaries might have been less than an educated man in the field of medicine.

As far as Plutarch is concerned, his familiarity with Greek medicine and with Hippocrates, in particular, is unquestionable. The relation between the Parallel lives and Medicine has been investigated in detail, leading to the identification of about six hundred of medical references. ${ }^{86} \mathrm{~A}$ comparison with the technical, medical sources proves the genuineness of Plutarch's descriptions. In particular, the Corpus Hippocraticum has been identified as the main source for diseases and wounds referring to biographies corresponding to the $4^{\text {th }}-3^{\text {rd }}$ BC. Furthermore, numerous plutarchean passages, for which it has been possible to identify the Hippocratic source, have proved the direct knowledge by Plutarch of Hippocratic works ${ }^{87}$ Finally, in a previous episode

81 Antela-Bernárdez, Borja, Sierra Martin, César (2018), Alexander and the Medicine, Karanos, 1, (1), 35-54.

82 Ilberg, Johannes (1927). Vita Hippocratis secundum Soranum (VHSS), in Sorani Gynaeciorum Libri IV, Leipzig and Berlin; B.G. Teubner, = Corpus medicorum graecorum (CMG), IV, 175-178; Adler, A. (1928-1938), SuidaeLexicon, iota, 564; Tzetzes, Ioannes (1826), Historiarum variarum chiliades 7.155, ed. T. Kiesselin, Leipzig; Teubner, 276-277.

83 Rackam, Harris (1959). Aristotle Politics, London; William Heinemann Ltd.; Cambridge, MA; Harvard University Press, 3.1282a, 227, "But 'physician' means both the ordinary practitioner, and the master of the craft, and thirdly, the man who has studied medicine as part of his general education."

84 Plutarch, Parallel lives, Alex. 8.1, "In my opinion, Alexander's love of the art of healing was inculcated to him by Aristotle pre-eminently. For he was not only fond of the theory of medicine, but actually came to aid of his friends when they were sick, and prescribed for them certain treatments and regimens, as one can gather from his letters.", English translation by Perrin, B. (1914), 243.

85 Antela-Bernárdez, B., Sierra Martin, C. (2018), 35.

86 Corvisier, Jean-Nicolas (1994), Médecine et biographie: l'exemple de Plutarque, Revue d'Etudes Grecques, 107, 129-157.

87 Andò, Valeria (2005), La ricezione ippocratica in Plutarco, in Gallo, Italo ed., La Biblioteca di Plutarco, Napoli; M. D'Auria (2005), 159-184. 
of Alexander's life, Plutarch referred to the loss of the voice as suggested by Hippocrates, i.e. within the context of a loss of consciousness. ${ }^{88}$ After drinking a drug prepared by his physician Philip of Acarnania, Alexander lost consciousness. Plutarch said that Alexander fell into a swoon ( $\lambda ı \pi 0 \theta v \mu i \alpha \varsigma$

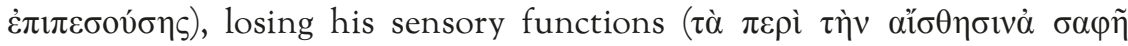
$\gamma \varepsilon v \varepsilon \dot{\varepsilon} \sigma \theta \alpha$ ), as well as the voice ( $\varphi \omega v \eta \dot{v} \dot{\varepsilon} \pi \imath \lambda \imath \pi \varepsilon \tau v)$. This description is remarkably similar to a syncopal episode reported by Hippocrates in Epidemics that occurred to a febrile Polycrates who fainted and remained seemingly life-

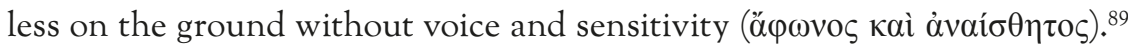
Commenting Polycrates' case, Roberto Lo Presti pointed out that 'the loss of the voice is part of what appears to be a real clinical definition of the "unconscious state". 90 The same might apply to Plutarch's description of Alexander's incident.

As far as Arrian is concerned, there is no direct proof of his knowledge of Hippocratic medicine. However, the cultural status of Arrian was far above the standard. He was born in a region of the Hellenistic Roman Empire known for its advanced medicine. His contemporary Soranus, who practised his profession in Rome when Arrian was a consul ( $330 \mathrm{AD}$ ), also came from the region as did Galen. Arrian quickly improved his ranking in the Roman hierarchy and ultimately became the governor of Cappadocia. This was an exceptional achievement for a Greek-born Roman citizen. In his youth, Arrian had been a student of the philosopher Epictetus of Hierapolis 50 ca-I25/130 AD ca.), whose lessons and discourses he collected and published in Greek. In this work, Arrian quoted Hippocrates four times, always referring to his specific condition as a physician. ${ }^{91}$ Later, in his Anabasis, Arrian demonstrates knowledge of Hippocrates' life. He quotes Critodemus, one of Alexander's physicians, as a physician of Cos and an Asclepiad by birth. ${ }^{92}$

\footnotetext{
Plutarch, Parallel lives, Alex., 19.

Épidémies, VII, 14, (Littré, V, 364-367).

Lo Presti, R. (2009), 55.

91 Schenkl, Heinrich (1916). Epicteti Dissertationes ab Arriano digestae, Leipzig; Heinrich Schenkl Editor, thereafter abbreviated as Schenkl; "What then? Was not Plato a philosopher? Yes, and was not Hippocrates, a physician? But you see how eloquently Hippocrates expresses himself. Does Hippocrates, then, expresses himself so eloquently by virtue of his being a physician (I, 8, 11-12, Schenkl, 36);' 'Suppose, for example, that you make the same sort of remark to the physicians: "Why, who among us did not use terms healthy and diseased before Hippocrates was born?” (II, 17, 8, 20-1, Schenkl, 178-179),' English edition and translation by Oldfather, William Abbot (1959). Epictetus the Discourses, as reported by Arrian, the manual, and fragments, Cambridge, Mass.; Harvard University Press; London; William Heinemann, Ltd., vol 1, 63 and 339. 
Given that Hippocrates was also of Cos and known as an Asclepiad son of Herakleides, Arrian seems to be implying that Critodemus shared with Hippocrates both the same birthplace and genus. Based on these, it would be hard to argue that such a highly respected personality like Arrian was ignorant of Hippocratic medicine.

\section{Conclusions}

The absence of Alexander's corpse precludes the possibility to conclude positively for a specific disease as the cause of death. Retrospective diagnosis based only on literary sources is bound to remain uncertain, because of contradictions between them. However, based on accounts of Alexander's death by Plutarch and Arrian (the only historians providing sufficient and coherent details), it seems possible to propose a sound hypothesis. During thirteen days of illness, Alexander displayed a fever of the remittent type. At the final stages of the disease, he became ö $\varphi \omega v o s$. Since this term was used in Hippocratic and Galenic medicine to denote patients sharing a serious depression of consciousness and motility (among which is cataleptic) and given the clinical resemblance between catalepsy and the typhoid state, this would suggest that Alexander was speechless because he was in a stupor. This, in turn, supports the typhoid fever hypothesis. In conclusion, it seems reasonable to conclude that Alexander the Great, whose life was extraordinary and unique in the history of humankind, died like a common man from an ordinary death. 


\section{BiBLIOGRAPHY}

1. Adams, Francis (1849). The genuine works of Hippocrates, London; The Sydenham Society, 315-316.

2. Adler, Ada (1928-1938). Suidae Lexicon, Leipzig; Teubner.

3. Adler, Richard, Mara, Elise (2016). Typhoid Fever: A History, Jefferson, NC; McFarland.

4. Amman, Johann Conradus (1722). Caelii Aureliani Siccensis De Morbis Acutis \& Chronicis Libri VIII, Amstelaedami; Ex Officina Wetsteniana.

5. Andò, Valeria (2005), La ricezione ippocratica in Plutarco', in Gallo, Italo ed., La Biblioteca di Plutarco, Napoli; M. D’Auria,2005, 159-184.

6. Antela-Bernárdez, Borja, Sierra Martin, César (2018), Alexander and the Medicine, Karanos, 1 (1), 35-54.

7. Baynham, Elizabeth (2003), The ancient evidence for Alexander the Great, in Roisman, Joseph ed., Brill's companion to Alexander the Great, Leiden/Boston; Brill, 2003, 3-30.

8. Bosworth, Brian A. (1971), The death of Alexander the Great: rumour and propaganda, Classical Quarterly, 21 (1), 112-36.

9. Bosworth, Brian A. (1980). A Historical Commentary on Arrian's History of Alexander, Oxford: Clarendon Press; New York Oxford University Press.

10. Byl, Simon (2006), Le délire hippocratique dans son contexte, Revue Belge de Philologie et Histoire, 84, 5-24.

11. Chinnock, Edward J. (1884). The Anabasis of Alexander, London; Hodder and Stoughton, 333.

12. Cirillo, Vincent J. (2006), "Winged sponges": houseflies as carriers of typhoid fever in $19^{\text {th }}$ - and early $20^{\text {th }}$-century military camps, Perspectives in Biology and Medicine, 49 (1), 52-63.

13. Cirillo, Vincent J. (2014), Arthur Conan Doyle (1859-1930): Physician during the typhoid epidemic in the Anglo-Boer War (1899-1902), Journal of Medical Biography, 22, 2-8.

14. Coronelli, Fra' Vincenzo (1702). Biblioteca universale sacro-profana, antico-moderna, Venezia; Tivani, 52.

15. Corpus Medicorum Latinorum (1990-1993). vol. VI 1: Caelii Aureliani Celerum Passionum libri III - Tardarum passionum libri V, edidit G. Bendz, in linguam Germanicam transtulit I. Pape, Pars I: Cel. pass. lib. I-III; Tard. pass. lib. I-II; Pars II: Tard. pass. lib. III-V. Indices composuerunt J. Kollesch et D. Nickel, Berlin.

16. Corvisier, Jean-Nicolas (1994), Médecine et biographie: l'exemple de Plutarque, Revue d'Etudes Grecque, 107, 129-157. 
17. Cunha, Burke A. (2004), The death of Alexander the Great: malaria or typhoid fever? Infectious Diseases Clinics of North America, 18 (1), 53-63.

18. Damiani, Ernesto (2012). La piccola morte di Alessandro il Grande, Venezia; Marsilio.

19. Doherty, Paul (2004). The Death of Alexander the Great, London; Constable.

20. Drabkin, Israel Edward (1945), Notes on the text of Caelius Aurelianus, Transactions and Proceedings of American Philological Association, 76, 299-320.

21. Drabkin, Israel Edward (1950). Caelius Aurelianus. On acute Diseases and chronic Disease, Chicago; University of Chicago Press.

22. Dryden, John (1906). Plutarch's Lives, Boston; Little Brown, 252.

23. Dysert, Anna (2007), Capturing Medical Tradition: Caelius Aurelianus' On Acute Diseases, Hirundo: The McGill Journal of Classical Studies, 5, 161-73.

24. Fornaciari, Gino, Bianucci, Raffaella (2009), Francesco e Bianca: non fu arsenico - ecco le prove! Archeologia viva, 138, 78-81.

25. Galli, Massimo, Bernini, Flavia, Zehender, Gianguglielmo (2004), Letter to the Editor: Alexander the Great and West Nile virus encephalitis, Emerging Infectious Diseases, 10 (7), 1330-32.

26. Gamble, Nathan, Bloedow, Edmund F. (2017), A medical-historical examination of the death of Alexander the Great, Journal of Ancient History and Archaeology, 4.3, 18-2.

27. Grabenstein, John D., Pittman, Phillip R., Greenwood, John T., and Engler, Renata J.M. (2006), Immunization to protect the US Armed Forces: heritage, current practice and prospects, Epidemiological Reviews, 28 (1), 3-26.

28. Gray, Timothy J., Webb, Cameron E. (2014), A review of the epidemiological and clinical aspects of West Nile virus, International Journal of General Medicine, 7, 193-203.

29. Grote, George (1846-1856). History of Greece, London; J. M. Dent \& Co.; New York; E. P. Dutton \& Co.

30. Hall, Katherine (2018), Did Alexander the Great Die from Guillain-Barré Syndrome?, Ancient History Bulletin, 32 (3-4), 106-128.

31. Hammond, Nicholas G. (1983). Three historians of Alexander the Great. The so-called Vulgate authors, Diodorus, Justin and Curtius, Cambridge [Cambridgeshire]/ New York; Cambridge University Press.

32. Hammond, Nicholas G. (1988), The Royal Journal of Alexander, Historia, 37, 129-50.

33. Ilberg, Johannes (1927). Vita Hippocratis secundum Soranum (VHSS), in Sorani Gynaeciorum Libri IV, Leipzig and Berlin; B.G. Teubner, = Corpus medicorum graecorum (CMG), IV, 175-178. 
34. Jaccoud, Sigismond (1877). Traitée de pathologie interne, Paris; V. Adrien Delahaye et C., Libraires-Éditeurs.

35. Jones, William Henry Samuel (1959). Hippocrates, London; Loeb Classical Library.

36. Kühn, Karl Gottlob (1964-1965). In Hippocratis Aphorismos Commentarii I-VIII, in Claudi Galeni opera omnia, Editionem curavit D. Carolus Gottlob Kühn, vol. I-XX, [Lipsiae, 1821-1833 (= Hildesheim; Olms, 1964-1965)].

37. Lim, Matthew L., Murphy, Gerald S., Calloway, Margaret and Tribble, David (2005), History of U.S. military contribution to the study of diarrheal diseases, Military Medicine, 170 (supplementum 4), 30-8.

38. Littré, Émile (1840), A quali malattie si devono riferire in generale le storie delle malattie che Ippocrate ha collocato fra le Epidemie, che debbasi intendere per causo, per frenite e per letargo, Giornale delle Scienze Medico-Chirurgiche, LXXIII, 5-44.

39. Littré, Émile (1853), De la science des poisons considérée dans l'histoire, Revue des deux mondes, 4, 665-87.

40. Littré, Émile (1839-1861). in CEuvrescomplètesd'Hippocrate, Amsterdam; Adolf M. Hakkert, 1961-1962, reproduction of edition, Paris 1839-1861.

41. Lo Presti, Roberto (2009), Le rappresentazioni del corpo "anaisthētos" nel Corpus Hippocraticum: una 'via negativa' verso la conoscenza, I Quaderni del ramo d'oro, online 2, (92), 51-91

42. Marineli, Filio, Tsoucalas, Gregory, Karamanou, Marianna and Androutsos, George (2013), Mary Mallon (1869-1938) and the history of typhoid fever, Annals in Gastroenterology, 26 (2), 132-34.

43. Mayor, Adrienne (2014), Alexander the Great: a questionable death, in Wexler, Philip ed., History of Toxicology and Environmental Health, toxicology in antiquity, vol. 1, Amsterdam; Elsevier, 2014, 52-9.

44. Montiglio, Silvia (2000). Silence in the land of logos, Princeton; Princeton University Press.

45. Motherby, George (1775). A new Medical Dictionary, London; Johnson \& Robinson.

46. Mphaka, Makgomo R., Moshime, Mpho, Tsilo, Lipontseng C. and Reddy, Carl (2019), Risk Factors Associated With Malaria Mortality in Tshwane District, South Africa: A Retrospective Cohort Study, 2011-2014, Fortune Journal of Health Sciences, 2 (2), 30-9.

47. Muramoto, Osamu (2014), Retrospective diagnosis of a famous historical figure: ontological, epistemic, and ethical considerations, Philosophy, Ethics and Humanities in Medicine, 9(10), 1-15. 
48. Nysten, Pierre-Hubert, Littré, Émile, Robin, Charles (1855). Dictionnaire de Médecine, de chirurgie, de pharmacie des sciences accessories et de vétérinarie de P.H. Nysten, Ch. Robin, Paris; Chez J.-B. Baillière.

49. Oldfather, Charles H. (1963). Diodorus Siculus. Diodorus of Sicily in Twelve Volumes, Cambridge, Mass.; Harvard University Press; London; William Heinemann, Ltd., vol. 8, 467-468.

50. Oldfather, William Abbot (1959). Epictetus the Discourses, as reported by Arrian, the manual, and fragments, Cambridge, Mass.; Harvard University Press; London; William Heinemann, Ltd., vol 1, 63 and 339.

51. Ongaro, Giuseppe (2008). Dal typhos all'ileotifo, in Storie di Medici e di Medicina, Padova; Cleup, 17-36.

52. Papagrigorakis, Manolis J., Yapijakis, Christos, Synodinos, Philippos N. and Baziotopoulou-Valavani, Effie (2006), DNA examination of ancient dental pulp incriminates typhoid fever as a probable cause of the Plague of Athens, International Journal of Infectious Diseases, 10 (3), 206-14.

53. Pearson, Lionel (1960). The lost histories of Alexander the Great, New York; American Philological Association, 434.

54. Philips, Graham (2004). Alexander the Great: Murder in Babylon, London; Virgin books.

55. Perrin, Bernadotte (1914). Plutarch: Lives, vol. VII: Demosthenes and Cicero, Alexander and Cesar, London; William Heinemann; New York; The MacMillan Co.

56. Rackam, Harris (1959). Aristotle Politics, London; William Heinemann Ltd.; Cambridge, MA; Harvard University Press, 227.

57. Retief, Francois P. (2005), The death of Alexander the Great, Acta Theologica, 7 Supplementum, 14-28.

58. Robson, Iliff (1966). Arrian, vol. II, London; William Heinemann LTD; Cambridge, Massachusetts; Harvard University Press, 289-293.

59. Roderico a Fonseca (1678). Commentaria in septem libros Aphorismorum Hippocratis, Patavii; Iacobi de Cadorinis, 349-350.

60. Roumagnac, Philippe, Weill, François-Xavier, Dolecek, Christiane, Baker, Stephen, Brisse, Sylvain et. al (2006), Evolutionary history of Salmonella typhi, Science, 314 (5803), 1301-304.

61. Roussille-Chamseru, Jean François Jacques (1798), Observations médicales, extraitesd'auteurs non médecins, appliquées à la description des fièvressubintrantes, et devant faire partie d'un plus grand travail, Mémoires de la Société Médicaled'émulation, 1, 4-23.

62. Sainte Croix, Guillaume-Emmanuel-Joseph Guilhem de Clermont-Lodève, baron de (1775). Examen critique des ancienshistoriensd'Alexandre-le-Grand, Paris; Henry Grand, Bachelier. 
63. Schenkl, Heinrich (1916). Epicteti Dissertationes ab Arriano digestae, Leipzig; Heinrich Schenkl Editor.

64. Schep, Leo J., Slaughter, Robin J., Vale, Allister J. and Wheatley, Pat (2014), Was the death of Alexander the Great due to poisoning? Was it Veratrum album?, Clinical Toxicology, 52 (1), $72-7$.

65. Stok, Fabio (2000), Note sul lessico della patologia in Celio Aureliano, in Sconocchia, Sergio, Toneatto, Lucio eds., Lingue tecniche del greco e del latino, III. Atti del III Seminario internazionale sulla letteratura scientifica e tecnica greca e latina, Bologna; Patron, 2000, 147-67.

66. Stoneman, Richard (1991). The Greek Alexander Romance, London; Penguin classics.

67. Strümpell, Adolf (1887). A textbook of Medicine for students and practitioners, New York; D. Appleton and Company.

68. Tardieu, Guy (1942), Le typhus. Étude physio-pathologique de l'atteinte du diencéphale au cours de la fièvretyphoïde, Presse médicale, 50 (7-8), 75-8.

69. Teodori, Ugo (1976). Trattato di Patologia medica, Roma; S.E.U.

70. Tzetzes, Ioannes (1826). Historiarum variorum chiliades 7.155, ed. T. Kiesselin, Leipzig; Teubner, 276-277.

71. Van der Eijk, Philip J. (2000). Diocles of Carystus A collection of the fragments with translation and commentary, Leiden/Boston/Koln; Brill.

72. Verghese, Abraham (1985), The Typhoid State revisited, American Journal of Medicine, 79 (3), 370-72.

73. Vincent, William (1797). The voyage of Nearchus from the Indus to the Euphrates; collected from the original journals, preserved by Arrian, London; T. Cadell, jun. and W. Davies.

74. Wiart, Christophe (2014), A note on Conium maculatum L., the plant that defeated Alexander the Great, Clin Toxicol, 6 (52), 645.

75. Waterfield, Robin (2019). Diodorus of Sicily The Library, Books 16-20, Oxford; Oxford University Press, Appendix 1, 537-42.

76. Watson, John S. (1853). Justin, Cornelius Nepos and Eutropius, literally translated with notes and a general index, London; Henry G. Bohn, York Street, Covent Garden, 117-20.

77. Wunderlich, Carl A. (1868). Das Verhalten der Eigenwärme in Krankheiten, Leipzig; Verlag von Otto Wigand.

78. Wunderlich, Carl A. (1871). On the Temperature in diseases: a manual of medical thermometry. Translated by W. Bathurst Woodman, London. 


\section{APPENDIX}

TABLE 1

Possible natural causes of Alexander's death, according to the scientific literature

\begin{tabular}{|c|c|c|}
\hline Genre of disease & Number of works & Specific disease \\
\hline Infectious diseases & 42 & $\begin{array}{l}\text { Malaria without any specification (7) } \\
\text { Malignant tertiary malaria }(7) \\
\text { Infective fever without any } \\
\text { specification (6) } \\
\text { Typhoid fever (9) } \\
\text { Yellow fever (5) } \\
\text { West Nile encephalitis (2) } \\
\text { Bacterial pneumonia (2) } \\
\text { Amoebic liver abscess (3) } \\
\text { Katayama fever (acute } \\
\text { schistosomiasis by S. haematobium) (I) }\end{array}$ \\
\hline $\begin{array}{c}\text { Fever of undetermined } \\
\text { origin }\end{array}$ & I & \\
\hline $\begin{array}{c}\text { Pathology of surgical } \\
\text { interest }\end{array}$ & II & $\begin{array}{l}\text { Cholecystitis from gallstones } \\
\text { Acute necrotizing pancreatitis } \\
\text { Spontaneous oesophageal rupture } \\
\text { following vomiting (Boerhaave } \\
\text { syndrome) } \\
\text { Perforated peptic ulcer } \\
\text { Acute surgical complication } \\
\text { following alcohol ingestion }\end{array}$ \\
\hline
\end{tabular}

Toxic or degenerative

pathology related to alcohol

\begin{tabular}{lcc}
\hline Metabolic disorders & I & Acute intermittent porphyria \\
\hline Psychiatric pathology & I & $\begin{array}{c}\text { Bereavement followed by } \\
\text { immunosuppression }\end{array}$ \\
\hline Vascular pathology & 2 & $\begin{array}{c}\text { A long-term complication of internal } \\
\text { carotid artery dissection following } \\
\text { trauma }\end{array}$ \\
& & $\begin{array}{c}\text { Ischemia of previously damaged } \\
\text { cerebral areas }\end{array}$ \\
\hline
\end{tabular}

\begin{tabular}{ccc}
\hline $\begin{array}{c}\text { Pathology of the } \\
\text { central and peripheral } \\
\text { nervous system }\end{array}$ & 2 & $\begin{array}{c}\text { Hypothalamic pathology } \\
\text { Guillain-Barré syndrome }\end{array}$ \\
\hline $\begin{array}{c}\text { Congenital } \\
\text { orthopaedic pathology }\end{array}$ & 2 & Klippel-Feil syndrome \\
\hline
\end{tabular}

Data are from Damiani, E. (2012) Appendix I, 20-24 and from note 3. The total of diagnostic hypothesis exceeds the number of papers (see notes 5 and $1_{3}$ ) because in some of them two different hypotheses are suggested. In the case of specific infectious disease, the number in parentheses indicates the number of papers. 
TABLE 2

Signs referring to Alexander's disease deducible from the narrations of Plutarch and Arrian

\begin{tabular}{|c|c|c|}
\hline & Plutarch & Arrian \\
\hline Beginning of symptoms & $\begin{array}{l}\text { After partying with } \\
\text { Medius }\end{array}$ & $\begin{array}{l}\text { After partying with } \\
\text { Medius }\end{array}$ \\
\hline Duration of disease & I3 days & I3 days \\
\hline Presence of fever & Yes & Yes \\
\hline Day of onset & I7 & I7 \\
\hline Last day of mention & 26 & 26 \\
\hline Type & Remittent & Remittent \\
\hline Shivering & No mention & No mention \\
\hline Sweating & No mention & No mention \\
\hline State of consciousness & $\begin{array}{l}\text { Mental orientation in space, } \\
\text { time, and person up to } 24 \\
\text { Stuporous from } 25 \text { to } 26 \\
\text { No further indication up } \\
\text { to death }\end{array}$ & $\begin{array}{l}\text { Mental orientation in space, } \\
\text { time, and person up to } 24 \\
\text { Stuporous on } 26 \\
\text { No further indication up } \\
\text { to death }\end{array}$ \\
\hline Briefing and Planning & Up to 22 & Up to 23 \\
\hline Issuing orders & Up to 24 & Up to 24 \\
\hline Worshipping & Up to 24 & Up to 24 \\
\hline Attitude and decubitus & $\begin{array}{l}\text { Moves independently in } \\
\text { bed without limitation up }\end{array}$ & $\begin{array}{l}\text { Moves independently in } \\
\text { bed without limitation up }\end{array}$ \\
\hline Active and indifferent & to 24 & to 24 \\
\hline Obliged & From 25 & From 25 \\
\hline \multicolumn{3}{|l|}{ Motility } \\
\hline Active & Up to $2 \mathrm{I}$ & Up to $2 \mathrm{I}$ \\
\hline Passive & Up to 25 & Up to 25 \\
\hline Dyskinesias & No mention & Face, hand on 26 Daesius? \\
\hline \multicolumn{3}{|l|}{$\begin{array}{l}\text { Organ-specific } \\
\text { Symptomatology }\end{array}$} \\
\hline Chest pain & No mention & No mention \\
\hline Cough & No mention & No mention \\
\hline Vomit & No mention & No mention \\
\hline Diarrhoea & No mention & No mention \\
\hline Dyspnoea & No mention & No mention \\
\hline \multicolumn{3}{|l|}{ Alterations of skin } \\
\hline Colour & No mention & No mention \\
\hline Rushes & No mention & No mention \\
\hline Haemorrhage & No mention & No mention \\
\hline Voice & Maintained up to 24 & Maintained up to 24 \\
\hline & Speechless since 25 & $\begin{array}{l}\text { Unable to talk on } 25 \\
\text { Speechless since } 26\end{array}$ \\
\hline \multicolumn{3}{|l|}{ Others } \\
\hline Eating & Last mention on I9 & Last mention on 19 \\
\hline Sleeping & Last mention on 25 & Last mention on 18 \\
\hline Bathing & Last mention on 20 & Last mention on $2 \mathrm{I}$ \\
\hline
\end{tabular}

The date indicated refers to the Daesius month. 
TABLE 3

The trend of Alexander's fever as described by Plutarch and Arrian

\begin{tabular}{|c|c|c|c|c|}
\hline \multirow{2}{*}{$\begin{array}{l}\text { Day } \\
\text { (Daesius } \\
\text { month) }\end{array}$} & \multicolumn{2}{|c|}{ Plutarch } & \multicolumn{2}{|c|}{ Arrian } \\
\hline & Perrin & Dryden & Robson & Chinnock \\
\hline 16 & - & - & - & - \\
\hline I7 & $\begin{array}{l}\text { He began to } \\
\text { have fever }\end{array}$ & $\begin{array}{c}\text { He was attacked } \\
\text { with fever }\end{array}$ & $\begin{array}{l}\text { Slept just where } \\
\text { he was, the } \\
\text { fever being } \\
\text { already upon } \\
\text { him }\end{array}$ & $\begin{array}{l}\text { After retir- } \\
\text { ing,,,he already } \\
\text { felt feverish }\end{array}$ \\
\hline 18 & $\begin{array}{c}\text { He slept in the } \\
\text { bath because he } \\
\text { had a fever }\end{array}$ & $\begin{array}{c}\text { He slept in the } \\
\text { bath on account } \\
\text { of his fever }\end{array}$ & - & - \\
\hline I9 & $\begin{array}{c}\text { He had a fever } \\
\text { through the } \\
\text { night }\end{array}$ & $\begin{array}{c}\text { He had the fever } \\
\text { on him through } \\
\text { the night }\end{array}$ & $\begin{array}{l}\text { Remained in } \\
\text { high fever the } \\
\text { whole night/ }\end{array}$ & $\begin{array}{l}\text { The fever raged } \\
\text { all night with- } \\
\text { out intermission }\end{array}$ \\
\hline 20 & - & - & - & - \\
\hline $2 \mathrm{I}$ & $\begin{array}{l}\text {....and was still } \\
\text { more inflamed } \\
\text { and during the } \\
\text { night he was } \\
\text { in a grievous } \\
\text { plight }\end{array}$ & $\begin{array}{l}\text {...his fever still } \\
\text { increasing and } \\
\text { suffered much } \\
\text { during the } \\
\text { night }\end{array}$ & $\begin{array}{l}\text { After sacrificing } \\
\text { continued in a } \\
\text { constant fever... } \\
\text { after bathing, } \\
\text { he was now } \\
\text { very ill }\end{array}$ & $\begin{array}{l}\text { He did not cease } \\
\text { to suffer from } \\
\text { fever...in the } \\
\text { evening he was } \\
\text { very ill }\end{array}$ \\
\hline 22 & $\begin{array}{l}\text {...his fever was } \\
\text { very high }\end{array}$ & $\begin{array}{l}\text { The fever was } \\
\text { very violent }\end{array}$ & $\begin{array}{c}\text {...and ill though } \\
\text { he was... }\end{array}$ & $\begin{array}{c}\text {...He was now } \\
\text { very dangerous- } \\
\text { ly ill }\end{array}$ \\
\hline 23 & - & - & - & - \\
\hline 24 & $\begin{array}{c}\text { His fever was } \\
\text { violent }\end{array}$ & $\begin{array}{c}\text { He was much } \\
\text { worse }\end{array}$ & $\begin{array}{l}\text { Now being al- } \\
\text { together ill...all } \\
\text { the night he was } \\
\text { in high fever }\end{array}$ & $\begin{array}{l}\text { He was now } \\
\text { very ill...during } \\
\text { the ensuing } \\
\text { night he was in } \\
\text { a very high fever }\end{array}$ \\
\hline 25 & $\begin{array}{c}\text { His fever did } \\
\text { not abate...he } \\
\text { was speechless }\end{array}$ & $\begin{array}{c}\text {...his fever did } \\
\text { not abate, he } \\
\text { was speechless }\end{array}$ & $\begin{array}{l}\text { Day and the } \\
\text { next night he } \\
\text { was in high } \\
\text { fever }\end{array}$ & $\begin{array}{l}\text { Day and ensu- } \\
\text { ing night he was } \\
\text { in a very high } \\
\text { fever }\end{array}$ \\
\hline 26 & $\begin{array}{c}\text { His fever did } \\
\text { not abate...he } \\
\text { was speechless }\end{array}$ & $\begin{array}{l}\text {...his fever did } \\
\text { not abate, he } \\
\text { was speechless }\end{array}$ & $\begin{array}{c}\text { He was in a high } \\
\text { fever }\end{array}$ & $\begin{array}{c}\text { He was in a very } \\
\text { high fever }\end{array}$ \\
\hline
\end{tabular}

Two translations are compared for each author, to account for possible linguistic nuances. The sources for the quoted passages are Perrin, B. (1914), 433-35; Dryden, John (1906). Plutarch's Lives. The Translation called Dryden's. Corrected from the Greek and Revised by A.H. Clough, vol. IV, Boston; Little Brown, 252-53; Robson, Iliff (I966). Arrian, vol. II, London; William Heinemann LTD; Cambridge, Massachusetts; Harvard University Press, 289-93; Chinnock, E. (I884), 4I8-20. 
TABLE 4

Side-by-side comparison of description of $\dot{\alpha} \varphi \omega v i \alpha$ by Hippocrates and of typhoid state by Osler and Strümpell

\begin{tabular}{|c|c|c|}
\hline Hippocrates & Osler & Strümpell \\
\hline $\begin{array}{l}\text { The eyes are fixed with- } \\
\text { out any movement of the } \\
\text { eyelids, }\end{array}$ & $\begin{array}{l}\text { The eyes may be open, } \\
\text { but he is oblivious } \\
\text { to all surrounding } \\
\text { circumstances }\end{array}$ & $\begin{array}{l}\text { We have repeatedly seen } \\
\text { patients almost motion- } \\
\text { less in bed, with eyes } \\
\text { open }\end{array}$ \\
\hline $\begin{array}{l}\text { the hands are carelessly } \\
\text { spreadeagled and thrown } \\
\text { apart }\end{array}$ & $\begin{array}{l}\text { He picks at bedclothes } \\
\text { or grasps at invisible } \\
\text { objects. }\end{array}$ & $\begin{array}{c}\text { Tendon reflexes and } \\
\text { mechanical excitability } \\
\text { of muscles are much } \\
\text { increased. }\end{array}$ \\
\hline they gnash their teeth, & $\begin{array}{c}\text { The lips and tongue are } \\
\text { tremulous }\end{array}$ & $\begin{array}{l}\text { In severe cases the pa- } \\
\text { tient is observed to grind } \\
\text { the teeth together; this is } \\
\text { due to a cramp-like of the } \\
\text { muscles of mastication }\end{array}$ \\
\hline $\begin{array}{l}\text { there is a spasm of the } \\
\qquad \operatorname{limbs...}\end{array}$ & $\begin{array}{l}\text { There is twitching of the } \\
\text { fingers and wrists-sub- } \\
\text { sultus tendinum and } \\
\text { carphologia }\end{array}$ & $\begin{array}{l}\text { There is a slight twitch- } \\
\text { ing of the muscles of the } \\
\text { face and extremities. } \\
\text { The old authorities gave } \\
\text { the name subsultus } \\
\text { tendinum... }\end{array}$ \\
\hline $\begin{array}{c}\text {...and convulsive } \\
\text { movement of the jaw } \\
\text { muscles called by Greeks } \\
\text { siagonitai }\end{array}$ & & $\begin{array}{l}\text { We often see persistent } \\
\text { tremor lower jaw. }\end{array}$ \\
\hline
\end{tabular}

\section{SAŽETAK}

Iako odsutnost tijela sprječava sigurne zaključke, smrt Aleksandra Velikog ostaje atraktivna tema retrospektivne dijagnoze. Zbog kriva tumačenja drevnih izvora, u znanstvenoj su literaturi Aleksandrovoj smrti pripisivani svi mogući prirodni uzroci. U prethodnim je radovima, na temelju prisutnosti remitentne groznice tipične za ovu bolest u pripovijedanjima Plutarha i Arriana, predložena pretpostavka da je Aleksandra ubila tifusna groznica. U ovom radu donosimo dodatne dokaze o prisustnosti stupora, drugoga karakterističnog simptoma tifusne groznice. Zapravo, na temelju autoriteta Celija Aurelijana $i$ Galena, po-

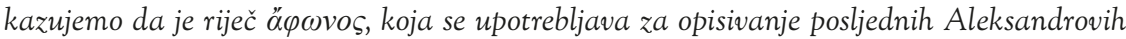
trenutaka, tehnička riječ iz leksikona Hipokratove patologije. Ta riječ, kojom se on služi, definira skupinu bolesti koje dijele ozbiljnu depresiju svijesti i motorike. Povezanost simptoma stupora s remitentnom groznicom jača pretpostavku o tifusnoj groznici.

Ključne riječi: smrt Aleksandra Velikog, remitentna groznica, stupor, afonija, Celije Aurelijan, Galen, Hipokrat, tifusno stanje 